\title{
Chemical Diabetes in the Adult Rat as the Spontaneous Evolution of Neonatal Diabetes
}

\author{
B. Portha ${ }^{1}$, L. Picon ${ }^{1}$, and G. Rosselin ${ }^{2}$ \\ ${ }^{1}$ Laboratoire de Physiologie du Développement, Université Paris VII, and ${ }^{2}$ Unité de Recherche de Diabétologie \\ et d'Etudes Radio-Immunologiques des Hormones Protéiques, Hôpital Saint-Antoine, Paris, France
}

Summary. Injection of streptozotocin in newborn rats induced a severe diabetic syndrome on day 4 after birth, with acute hyperglycaemia and glycosuria. Over the next 3 weeks spontaneous recovery occurred as attested by normal basal blood glucose and plasma insulin levels. Recovery was, however, incomplete in the adult since a definite impairment in insulin release and glucose disposal was observed. This state was characterized by the following features: 1) a $72 \%$ decrease in pancreatic insulin stores without change in pancreatic glucagon stores; 2) a slight but consistent elevation of blood glucose in the fasted and fed basal states and especially of blood glucose $90 \mathrm{~min}$ after an IV glucose load $(2 \mathrm{~g} / \mathrm{kg})$ performed under pentobarbitone anaesthesia; 3) a considerable decline in the glucose-induced insulin release with a decrease in the maximal response. Both early and late phases of insulin release were impaired, as indicated by in vivo glucose infusion experiments. Basal plasma glucagon levels were normal. Over a period of 12 months with a normal laboratory diet no aggravation of the chemical diabetic state was observed. This new experimental syndrome is a potentially interesting model for the study of the influence of environmental factors on the development of overt diabetes.

Key words: Chemical diabetes, streptozotocin, insulin, glucagon, endocrine pancreas, insulin secretion, glucose tolerance, age, sex, newborn rats.

We have previously shown that streptozotocin exerts diabetogenic activity in the newborn rat [17]. A severe diabetic syndrome develops on day 4 after treatment. Over the next 2 weeks spontaneous recovery takes place but is, however, incomplete as attested by abnormal in vivo insulin secretion and glucose tolerance when the pancreas is challenged with a glucose tolerance test. The present report describes a detailed characterization of the long term effect of streptozotocin treatment by a longitudinal study of animals from birth up to 12 months of age. The purpose of the study was: 1) to assess whether the failure of complete recovery from neonatal diabetes persisted in the adult; 2) in the case of a sustained pancreatic defect, to characterize its effects on glucose disposal.

\section{Materials and Methods}

\begin{abstract}
Animals
Albino rats (Sherman strain) bred in the laboratory were fed ad libitum with pelleted chow (U.A.R., Villemoisson s/Orge, France carbohydrate $47 \%$, protein $20 \%$, fat $8 \%$ ). Females were caged with a male for one night ( $5 \mathrm{p} . \mathrm{m}$. to 9 a. m.) and pregnancy was detected by abdominal palpation 14 days later. Natural birth occurred 22 days after mating. On the day of birth, the newborn rats received streptozotocin (Upjohn, Co., Kalamazoo, USA) (100 $\mu \mathrm{g} /$ g) in $25 \mu \mathrm{l}$ of citrate buffer $(0.05 \mathrm{~mol} / \mathrm{l}), \mathrm{pH} 4.5$, through the saphenous vein directly accessible by transcutaneous puncture. They were left with their own mothers, with the number of animals per litter kept at 8, since litter size has short [1] and long-term [14] influence on body weight and insulin release. On day 4 after birth, neonates were tested for glycosuria with Clinistix (Ames Co, Division Miles Labs, Paris, France) and only animals with $3+$ values were kept. They were weaned on day 21 after birth. In other litters all the newborn received only citrate buffer and were used as controls. Mortality in the streptozotocin-treated animals was similar ( 30 to $50 \%$ ) to that previously described [17]. The streptozotocin-treated male rats showed the same weight curve as normal males from birth to 12 months of age, while the treated females had a $10 \%$ lower body weight than age related normal females from one month to twelve months.
\end{abstract}

\section{Samples}

Neonatal blood samples were collected from axillary vessels and immediately centrifuged at $4^{\circ} \mathrm{C}$; plasma was stored at $-20^{\circ} \mathrm{C}$ until assayed. After dissection, the pancreas was weighed and homogenized for $1 \mathrm{~min}$ by ultrasonic disintegration at $4^{\circ} \mathrm{C}$ 
Table 1. Plasma and pancreatic insulin and glucagon showing in 4 day-old diabetic newborn rats. The diabetic group comprises those animals injected with streptozotocin $(100 \mathrm{mg} / \mathrm{kg})$ at birth and intense glycosuria (3+ Clinistix test) on day 4

\begin{tabular}{|c|c|c|c|c|c|c|}
\hline & \multirow{2}{*}{$\begin{array}{l}\text { Body weight } \\
\mathrm{g}\end{array}$} & \multirow{2}{*}{$\begin{array}{l}\text { Blood glucose } \\
\mathrm{mg} / 100 \mathrm{ml}\end{array}$} & \multicolumn{2}{|l|}{ Plasma } & \multicolumn{2}{|l|}{ Pancreatic } \\
\hline & & & $\begin{array}{l}\text { Insulin } \\
\mu U / \mathrm{ml}\end{array}$ & $\begin{array}{l}\text { Glucagon } \\
\mathrm{pg} / \mathrm{ml}\end{array}$ & $\begin{array}{l}\text { Insulin } \\
\mathrm{mU} / \mathrm{mg}\end{array}$ & $\begin{array}{l}\text { Glucagon } \\
\mathrm{ng} / \mathrm{mg}\end{array}$ \\
\hline Controls & $\begin{array}{l}8.3 \pm 0.4 \\
(10)\end{array}$ & $\begin{array}{r}108 \pm 1 \\
(10)\end{array}$ & $\begin{array}{c}46 \pm 6 \\
(18)\end{array}$ & $\begin{array}{c}959 \pm 44 \\
(8)\end{array}$ & $\begin{array}{c}10.4 \pm 0.7 \\
(10)\end{array}$ & $\begin{array}{c}58 \pm 4 \\
(7)\end{array}$ \\
\hline Diabetics & $\begin{array}{l}7.1 \pm 0.3^{\mathrm{a}} \\
(10)\end{array}$ & $\begin{array}{l}345 \pm 37^{\mathrm{b}} \\
(10)\end{array}$ & $\begin{array}{c}31 \pm 2^{\mathrm{a}} \\
(12)\end{array}$ & $\begin{array}{c}1300 \pm 139^{a} \\
(7)\end{array}$ & $0.8 \pm 0.1^{\mathrm{b}}$ & $\begin{array}{c}59 \pm 8 \\
(6)\end{array}$ \\
\hline
\end{tabular}

Values are mean \pm SEM. The number of observations is shown in parentheses

${ }^{a} \mathrm{p}<0.05$ when compared by the Student unpaired t-test with controls

b $\mathrm{p}<0.001$ when compared by the Student unpaired t-test with controls

Table 2. Plasma and pancreatic insulin and glucagon in 10 month-old female rats treated with streptozotocin at birth

\begin{tabular}{|c|c|c|c|c|c|c|}
\hline & & \multirow{2}{*}{$\begin{array}{l}\text { Blood glucose } \\
\mathrm{mg} / 100 \mathrm{ml}\end{array}$} & \multicolumn{2}{|l|}{ Plasma } & \multicolumn{2}{|l|}{ Pancreatic } \\
\hline & & & $\begin{array}{l}\text { Insulin } \\
\mu U / \mathrm{ml}\end{array}$ & $\begin{array}{l}\text { Glucagon } \\
\mathrm{pg} / \mathrm{ml}\end{array}$ & $\begin{array}{l}\text { Insulin } \\
\mathrm{mU} / \mathrm{mg}\end{array}$ & $\begin{array}{l}\text { Glucagon } \\
\mathrm{ng} / \mathrm{mg}\end{array}$ \\
\hline \multirow[t]{2}{*}{ Fed } & Controls & $\begin{array}{c}92 \pm 3 \\
(17)\end{array}$ & $\begin{array}{c}74 \pm 2 \\
(17)\end{array}$ & $\begin{array}{c}325 \pm 35 \\
(15)\end{array}$ & $\begin{array}{c}4.9 \pm 0.5 \\
(5)\end{array}$ & $\begin{array}{c}13.4 \pm 2.6 \\
(5)\end{array}$ \\
\hline & Streptozotocin treated & $\begin{array}{c}117 \pm 4^{b} \\
(16)\end{array}$ & $\begin{array}{c}49 \pm 5^{b} \\
(16)\end{array}$ & $\begin{array}{c}305 \pm 27 \\
(8)\end{array}$ & $\begin{array}{c}1.3 \pm 0.3^{\mathrm{b}} \\
(12)\end{array}$ & $\begin{array}{c}12.0 \pm 1.3 \\
\text { (12) }\end{array}$ \\
\hline \multirow[t]{2}{*}{$\begin{array}{l}\text { Fasted } \\
\text { (over night) }\end{array}$} & Controls & $\begin{array}{c}70 \pm 3 \\
(12)\end{array}$ & & & & \\
\hline & Streptozotocin treated & $\begin{array}{c}81 \pm 3^{a} \\
(12)\end{array}$ & & & & \\
\hline
\end{tabular}

Values are mean \pm SEM. The number of observations is shown in parentheses

${ }^{a} \mathrm{p}<0.05$ when compared by the Student unpaired t-test with related controls

${ }^{b} \mathrm{p}<0.001$ when compared by the Student unpaired t-test with related controls

(Sonifier Branson B 12, Heat Systems-Ultrasonics, Plainview, USA) in acid-alcohol solution ( $75 \%$ ethanol, $1.5 \% \mathrm{v} / \mathrm{v} 12 \mathrm{~mol} / \mathrm{l}$, $\mathrm{HCl}, 23.5 \%$ distilled water). After one night at $-20^{\circ} \mathrm{C}$, the extracts were centrifuged and the supernatants kept at $-20^{\circ} \mathrm{C}$ until assay.

Intravenous (IV) glucose tolerance tests were performed in 3 to 12 month-old adult animals in the fed state, after anaesthesia with sodium pentobarbitone ( $4 \mathrm{mg} / 100 \mathrm{mg}$ body weight IP). The saphenous vein was exposed and glucose (usually $2 \mathrm{~g} / \mathrm{kg}$ ) was injected over 30 to 60 seconds as a $25 \mathrm{~g} / 100 \mathrm{ml}$ solution in water. Sequential blood sampling $(400 \mu \mathrm{l})$ was obtained from the tail vein before and 2, 5, 15 and $90 \mathrm{~min}$ after the injection of glucose. In some experiments adult rats were tested with three different doses of glucose, $0.5,1.5$ and $3.0 \mathrm{~g} / \mathrm{kg}$; each dose was administered to the same animal in random order one week apart. The treated rats tolerated the procedure as well as the normal rats and recovered for later testing as described. Glucose tolerance was also studied in 3 month-old males using a priming dose of $180 \mathrm{mg}$ glucose and then a constant $45 \mathrm{~min}$ glucose infusion $(9 \mathrm{mg}$ of a $10 \mathrm{~g} / 100 \mathrm{ml}$ solution). Blood samples were collected before and at $5,10,20$, $30,40,45,50,60$ and $80 \mathrm{~min}$ after starting the infusion.

\section{Assays}

Blood glucose was measured by the glucose oxidase procedure [12]. In some experiments plasma glucose was determined using a glucose-analyser (Beckman Inc., Palo Alto, USA). Pancreatic and plasma immunoreactive insulin (IRI) were estimated using purified rat insulin as standard ( $\mathrm{R} 171$, Novo, Copenhagen, Denmark), antibody to human insulin [21] and porcine monoiodonated ${ }^{125}$ I-insulin [6]. The method allows the determination of $6 \mu \mathrm{U} / \mathrm{ml}(0.25 \mathrm{ng} / \mathrm{ml})$ with a coefficient of variation within and between assays of $10 \%$. Immunoreactive glucagon (IRG) was assayed in the pancreas according to a method previously described [13], using porcine monoiodinated ${ }^{125} \mathrm{I}$-glucagon as tracer [15] and porcine glucagon as standard (B $66 \mathrm{~K} \mathrm{1070,} \mathrm{Novo,}$ Dr. J.Schlichtkrull, Copenhagen, Denmark). In both radioimmunoassays, silicate was used to separate free from bound hormone [20]. Plasma IRG was determined on unextracted samples using the glucagon antibody $30 \mathrm{~K}$, porcine monoiodinated ${ }^{125} \mathrm{I}$ glucagon, porcine glucagon as standard and a charcoal-dextran separation technique [5].

\section{Calculations}

The insulin response during the glucose tolerance tests has been calculated as an insulinogenic index which is the ratio of the incremental plasma insulin values integrated over the period following the injection of glucose by the corresponding incremental integrated blood glucose values, as used by Rabinovitch and Cerasi [ 2 , 19]. Results are given as mean \pm SEM. Statistical analysis were performed using Student's unpaired t-test. 


\section{Results}

\section{1) Criteria of Streptozotocin-Diabetes in Neonates}

In order to detect diabetes in the neonates after intravenous injection of streptozotocin, daily glycosuria was tested with Clinistix in each surviving animal. In a group of 44 treated newborn, 30\% (12/ 41) were glycosuric on day 2 after birth, $57 \%(20 /$ $35)$ on day $3,67 \%(22 / 33)$ on day $4,36 \%(9 / 25)$ on day $5,17 \%(4 / 23)$ on day $6,14 \%(3 / 22)$ on day 7 and $0 \%(0 / 16)$ on day 9. Thus, most of these neonates developed glycosuria on day 4 after STZ treatment. It was confirmed that 4 day-old newborn rats exhibiting glycosuria were really diabetics by the following criteria (Table 1): blood glucose was high, $345 \pm 37 \mathrm{mg} / 100 \mathrm{ml}$, pancreatic insulin stores showed a $93 \%$ decrease, plasma insulin was significantly decreased and very low considering the high glucose level. On the other hand, plasma glucagon was significantly higher than the corresponding values of the controls. Pancreatic glucagon content was not affected.

Diabetic newborn rats were selected 4 days after birth on the basis of a $3+$ Clinistix test at that time. The neonatal diabetes of these animals was spontaneously reversible. To ascertain the period of recovery glycosuria was sought every two days up to day 21. In all animals tested glycosuria which had disappeared on day 9 after birth did not recur and 21 days after birth blood glucose and plasma insulin levels had returned to normal values: $106 \pm 9 \mathrm{mg} /$ $100 \mathrm{ml}$ and $36 \pm 2 \mu \mathrm{U} / \mathrm{ml}$, respectively, compared with $106 \pm 4 \mathrm{mg} / 100 \mathrm{ml}$ and $31 \pm 2 \mu \mathrm{U} / \mathrm{ml}$ in the controls.

\section{2) Long-term Study of Rats Treated with Streptozotocin at Birth}

a) Basal Characteristics of the 10 Month-Old Rats: In the treated animals the mean blood glucose level was slightly but significantly higher than in the controls in both the fasted and the fed state (Table 2); plasma and pancreatic insulin levels in the fed state were both significantly lower than in the controls. Plasma glucagon and pancreatic glucagon content were unchanged. Data in males, not shown here, were similar to those obtained in females.

b) Glucose Tolerance Test: In controls (Fig. 1) $15 \mathrm{~min}$ and $90 \mathrm{~min}$ after the glucose infusion blood glucose levels were significantly lower at 3 months $(257 \pm 20$ and $103 \pm 5 \mathrm{mg} / 100 \mathrm{ml})$ than at 21 days $(372 \pm 34$ and $143 \pm 17 \mathrm{mg} / 100 \mathrm{ml}$ ), probably reflecting improvement of glucose tolerance related to carbohydrate enrichment of the diet after weaning.

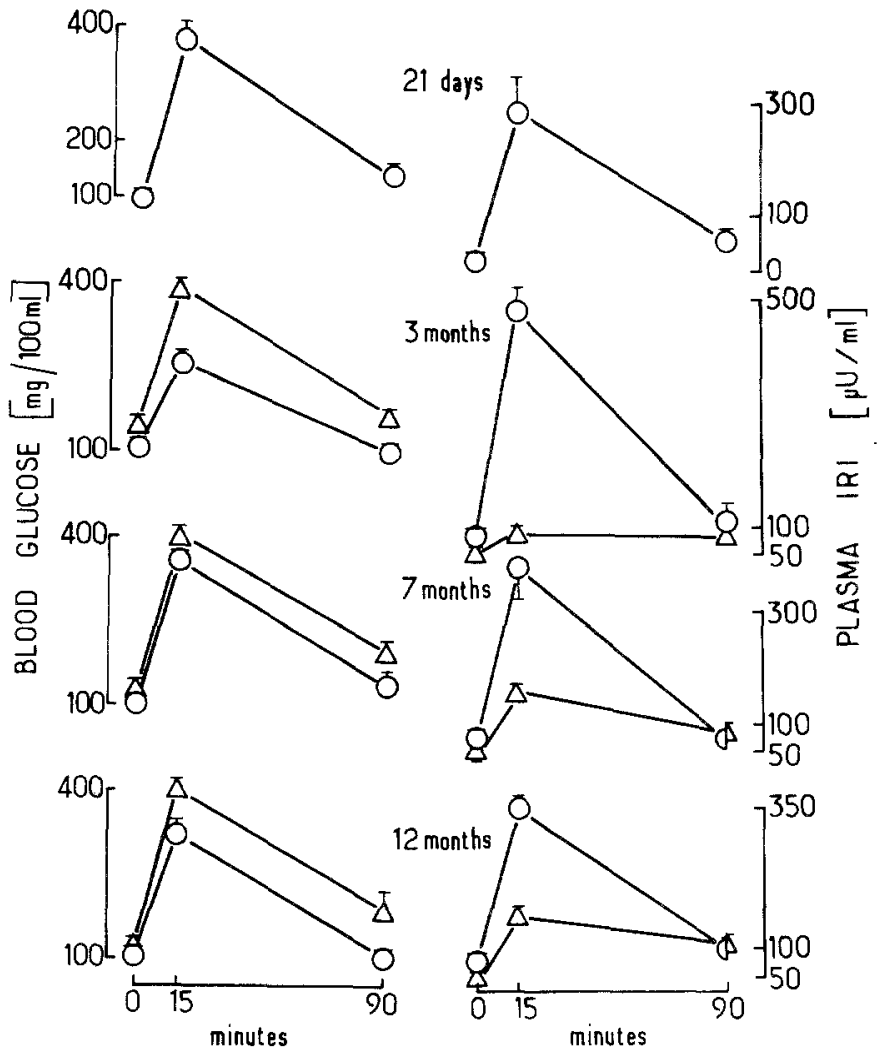

Fig. 1. Effect of age on IV glucose tolerance and plasma insulin response in females treated with streptozotocin (STZ) at birth. Each point is mean \pm SEM of from 5 to 6 animals for controls and 5 to 7 animals for streptozotocin-treated. The same animals were studied sequentially $O-O$ Normals, $\triangle-\triangle$ STZ-treated

In the streptozotocin treated groups the preinfusion blood glucose values were slightly elevated, reaching significance at 3 months and 12 months ( $p$ $<0.05$ ) when compared to their age-matched controls. At 7 months, the observed difference was not significant. The $90 \mathrm{~min}$ blood glucose values in the streptozotocin animals were always significantly higher than values in the age matched normal rats: $166 \pm 7$ and $103 \pm 6,194 \pm 22$ and $133 \pm 13$, and $184 \pm 34$ and $99 \pm 3 \mathrm{mg} / 100 \mathrm{ml}$ at 3,7 and 12 months, respectively. Glucose disposal was thus decreased in these animals, while age appeared to have no influence on the impairment of glucose tolerance.

c) Insulin Response: Insulin response to glucose load in control and streptozotocin treated rats is also shown in Fig. 1. In controls, it can be seen that the plasma insulin response is greater in 3 month-old females than in 7 and 12 month-old ones. In older rats plasma insulin response decreases. In the treated rats, the basal plasma insulin levels in the fed state were significantly lower than in the age-matched control rats only at 3 months. A considerable decrease 
Table 3. Preinfusion insulin to glucose ratios and insulinogenic indices ( $\Delta \mathrm{IRI} / \Delta$ Glucose) in female rats treated with streptozotocin at birth

\begin{tabular}{|c|c|c|c|c|c|c|c|}
\hline & $\begin{array}{l}\text { Age } \\
\text { (month) }\end{array}$ & $\begin{array}{l}\text { Preinfusion } \\
\text { IRI/Glucose }\end{array}$ & A & $\mathrm{B}$ & $\frac{\Delta \text { IRI }}{\Delta \text { Glucose }} \times 10^{3}$ & A & B \\
\hline Controls & 3 & $\begin{array}{c}0.74 \pm 0.03 \\
(6)\end{array}$ & & & $\begin{array}{c}3500 \pm 937 \\
(6)\end{array}$ & & \\
\hline Streptozotocin-treated & 3 & $\begin{array}{c}0.37 \pm 0.03 \\
(7)\end{array}$ & $<0.001$ & & $258 \pm 52$ & $<0.005$ & \\
\hline Controls & 12 & $\begin{array}{c}1.23 \pm 0.11 \\
(6)\end{array}$ & & $<0.005$ & $2271 \pm 123$ & & NS \\
\hline Streptozotocin-treated & 12 & $1.09 \pm 0.08$ & NS & $<0.001$ & $445 \pm 146$ & $<0.001$ & NS \\
\hline
\end{tabular}

Values are mean $\pm \mathrm{SEM}$. The number of observations is shown in parentheses. $\mathrm{A}=$ comparison of chemical diabetics and age-related controls. $\mathrm{B}=$ comparison of 12 month-old females to the corresponding 3 month-old females. NS $=$ not significiant
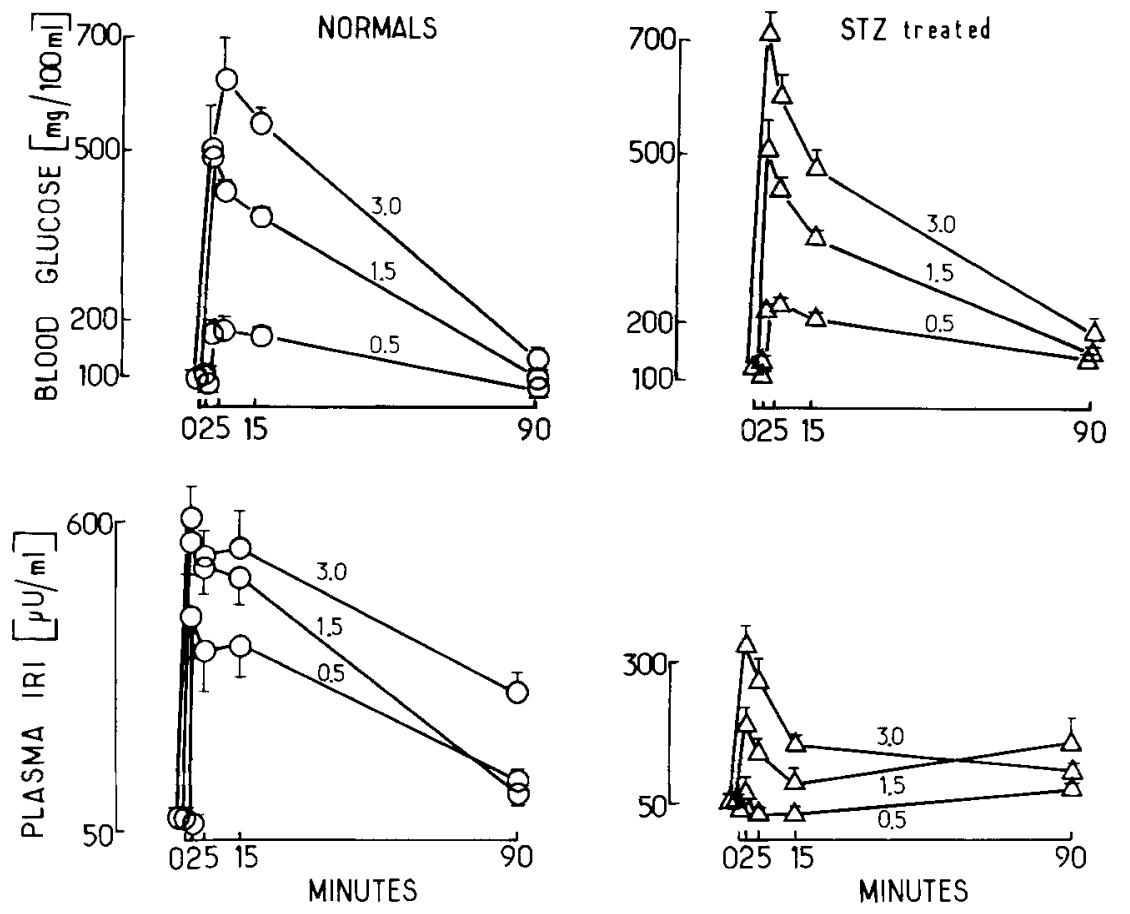

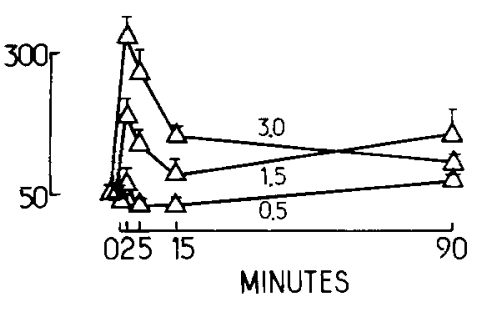

Fig. 2. Effect of different doses of glucose on IV glucose tolerance and plasma insulin response in rats treated with streptozotocin (STZ) at birth. Same animals were injected sequentially in random order one week apart with three doses of glucose, $0.5,1.5$ and $3.0 \mathrm{~g} / \mathrm{kg} \mathrm{IV}$. Each point is mean \pm SEM of 5 to 6 animals for controls and for streptozotocin-treated was observed in the 15 min insulin values at all ages. This abnormality of the insulin-glucose relationship was further analysed using the plasma insulin to blood glucose ratio (Table 3). The preinfusion insulin to glucose ratio was significantly decreased in the 3 month-old treated animals $(\mathrm{p}<0.001)$. After glucose load, the insulinogenic indices for the 3 and 12 month-old rats were decreased by $93 \%$ and $80 \%$, respectively, as compared with the controls.

Similar observations were obtained in male animals: no significant sex difference was detected in the drop of insulinogenic indices in treated males when compared with streptozotocin treated females.

\section{3) In Vivo Kinetic Studies of Insulin Secretion in Chemical Diabetic Rats}

a) Studies with Different Doses of Glucose: After IV injection of $0.5,1.5$ and $3.0 \mathrm{~g} / \mathrm{kg}$ glucose in 10 month-old female rats different blood glucose levels were achieved in normal and in streptozotocin treated animals (Fig. 2). The $90 \mathrm{~min}$ blood glucose levels in the treated rats were higher than in the normals: $140 \pm 6$ versus $80 \pm 4,150 \pm 14$ vs $99 \pm 3$ and $183 \pm 38$ vs $135 \pm 11 \mathrm{mg} / 100 \mathrm{ml}$ after $0.5,1.5$ and $3.0 \mathrm{~g} / \mathrm{kg}$ glucose injections, respectively. In spite of similar blood glucose concentrations at 2, 5 and $15 \mathrm{~min}$, mean plasma insulin levels were considerably 


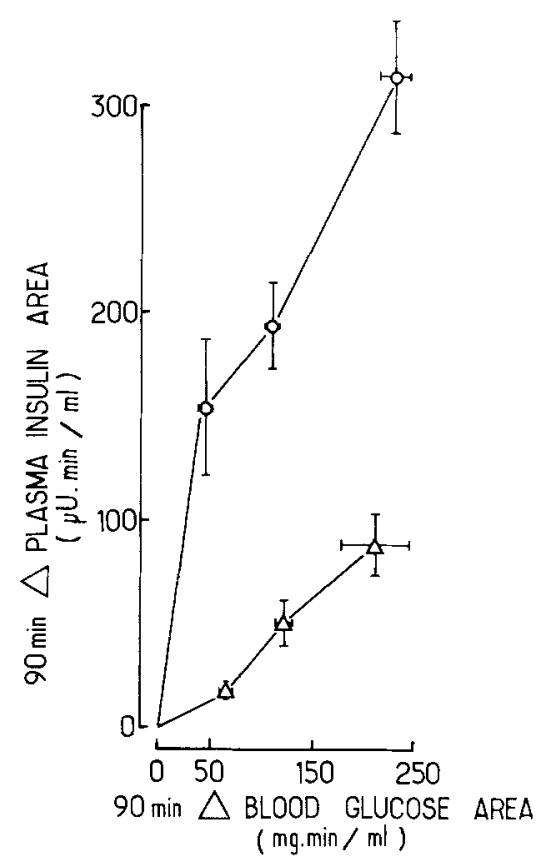

Fig. 3. Glucose dose-response curves in females treated with streptozotocin (STZ) at birth. Curves were obtained by plotting (on the ordinate) the mean \pm SEM increases $(\Delta)$ of plasma IRI concentration above the preinfusion value, integrated over the 90 minutes after injection of glucose $0.5,1.5$ and $3.0 \mathrm{~g} / \mathrm{kg}$, and (on the abscissa) the corresponding mean $\pm \mathrm{SEM} \Delta$ blood glucose area. The values are taken from Fig. $2 . \bigcirc-O$ Normals, $\triangle \longrightarrow \triangle \mathrm{STZ}$ treated

lower in the treated rats than in normals after the three doses of glucose (Fig. 2). Similar data (not shown here) were obtained with 10 month-old male rats. Even at high blood glucose levels the insulin responses in the SD rats were never equivalent to the response obtained in the normal rats. In chemical diabetic females the magnitude of the insulin response to glucose, that is the slope of the insulin area versus blood glucose area (Fig. 3), is decreased, particularly for a weak glucose increase with an approximate value of 0.6 , compared to a value of 8.0 in the normals. In the chemical diabetic males (result not shown here) the slope remains considerably decreased whatever the glucose increase.

b) Studies with Prolonged Glucose Infusion: Glucose was infused for $40 \mathrm{~min}$ in 3 month-old streptozotocin treated and normal male rats with the same body weight in order to study the insulin-glucose relationship at constant blood glucose level. The treated ani-

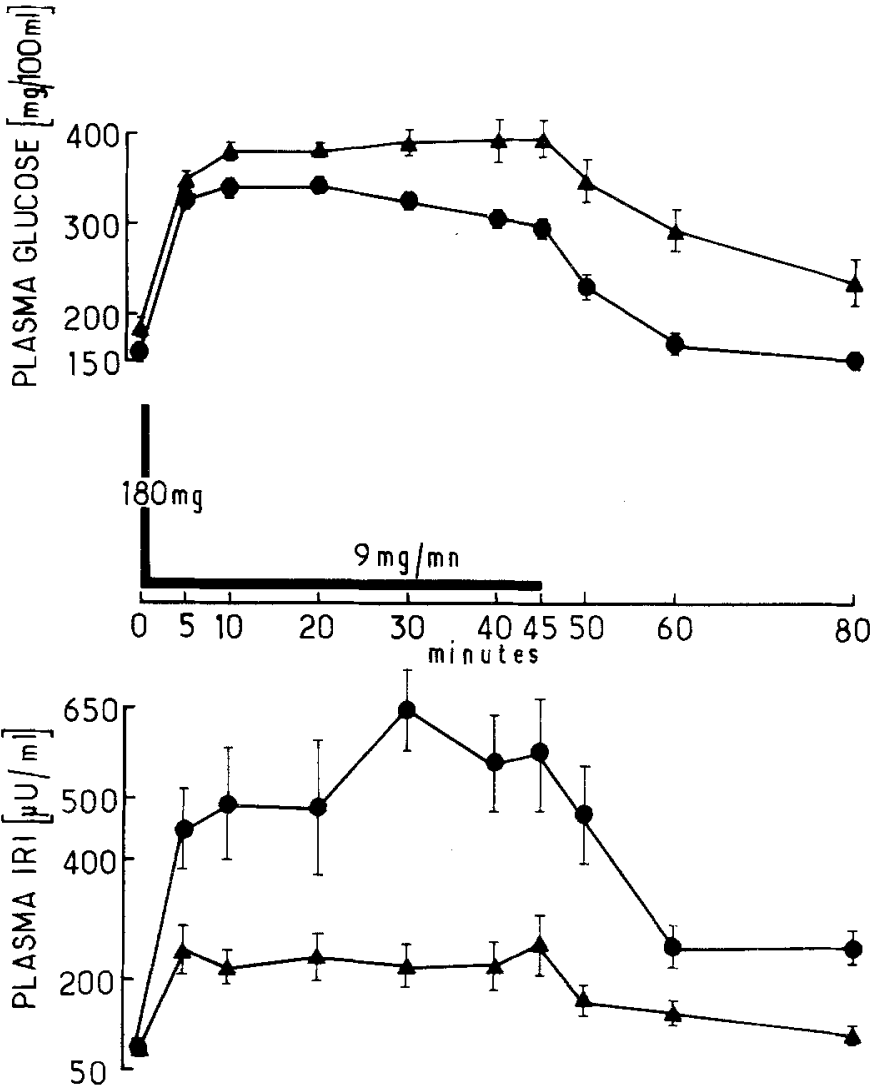

Fig. 4. Plasma glucose and plasma insulin (IRI) levels during a prolonged glucose infusion in males treated with streptozotocin (STZ) at birth. Glucose was administered as a rapid IV injection (180 $\mathrm{mg}$ ) followed by a constant infusion $(9 \mathrm{mg} / \mathrm{min})$ for $45 \mathrm{~min}$. Each point represents the mean \pm SEM of 11 animals for the controls and 8 animals for the streptozotocin-treated.

Normals, $\mathbf{\Delta}-\mathbf{S T Z}$ treated

mals exhibited higher plasma glucose levels than the controls (Fig. 4). This was significant during the infusion and $35 \mathrm{~min}$ after its cessation. The insulin response of the treated animals during the infusion was sustained for the duration of the glucose infusion as in the normal males, but was very low throughout.

\section{Discussion}

We have previously reported [17] the successful production of diabetes in fetal and neonatal rats by injecting a single dose of streptozotocin on the day of birth. Overt diabetes was maximal 4 days later and disappeared in 3 weeks. The data presented here confirm the previous results. The transitory nature of the overt beta cell deficiency appears to be a unique characteristic of diabetes in mammalian neonates as compared to diabetes in the adult and is confirmed by a recent observation in human neonates [22]. The 
recovery occurring in streptozotocin treated neonates is probably related to the fact that in neonates the rate of beta cell renewal is elevated, as suggested by study of in vitro DNA synthesis in isolated neonatal islets [11]. In contrast, there is a very limited capacity of beta cell proliferation in adult rodents with experimentally induced or hereditary diabetes (for review see 11). From the data presented here it appears that an early severe insult to the beta cell may induce a long term defect with the following features: 1) an impairment in pancreatic insulin stores without change in pancreatic glucagon stores; 2) a slight but consistent elevation of basal blood glucose in the fed and fasted states and of blood glucose $90 \mathrm{~min}$ after a glucose load; 3) a considerable decline in insulin release, with a large decrease in the insulin response to a glucose challenge. Glucose infusion experiments further indicate that both the early and late phases of insulin release are impaired.

In our experimental model this pattern of glucose tolerance and of diminished insulin response to glucose is clearly related to decreased insulin stores. In dogs treated with alloxan mild diabetes has been obtained with decreased early-phase insulin response to glucose and slower plasma glucose disappearance rate [18]. Insulin stores in the pancreas have not been determined; but with the partial pancreatectomy technique it has been demonstrated that deterioration of glucose tolerance develops only in dogs having less than $50 \%$ of the total pancreatic insulin remaining [25]. In the rodent Acomys there is also a decreased insulin response to glucose $[2,9,19]$, but the defect occurs in a pancreas with hyperplastic islets and with correspondingly elevated insulin content $[8,24]$. Although the destruction of beta cells in the rat neonate results in a definitive impairment of the endocrine pancreas, no overt diabetes occurred spontaneously throughout the study, up to 12 months. However, in preliminary experiments, in collaboration with Dr. Nicolaidis, some chemical diabetic female rats made hyperphagic by destruction of the ventromedial nucleus developed severe diabetes with glycosuria. This indicates that worsening of chemical diabetes in the rat arises from hyperphagia and accumulation of adipose tissue. This is of interest since there is considerable evidence of a correlation between obesity, due to hyperphagia, and diabetes in both man [16], and animals [3, 10, 23]. Further there is some evidence that obesity and/or associated hyperphagia during the prediabetic state may contribute to the development of frank diabetes in both man [16] and animals [4, 7].

Despite the dramatic decrease of insulin secretion there is no great abnormality in glucose tolerance. This suggests that some regulatory mechanism coun- teracts the lack of insulin secretion. The regulatory factor does not seem to be a decrease in plasma glucagon level, since it was found to be normal. It may be related to insulin sensitivity of the target tissues, since a subnormal blood glucose together with low insulin response suggests hypersensitivity to insulin in the chemical diabetic rats. This point is now under investigation.

Acknowledgements. We are grateful to Jean-Claude Cros and Bernard Chenut for expert technical assistance, to Alain Le Nédic for his excellent keeping of the chemical diabetic animals, and to Miss Chantal Brunet for her careful preparation of the manuscript. Streptozotocin was kindly provided by Dr. J. P. Paturaud (Upjohn France, Paris). This investigation has been supported by the Université Paris VII and the Institut National de la Santé et de Recherche Médicale (INSERM) (Contrat de Recherche Libre $\mathrm{N}^{\circ} 7610224$ ).

\section{References}

1. Asplund, F.: Effect of postnatal feeding on the functional maturation of pancreatic islet cells of the neonatal rats. Diabetologia 8, 153-159 (1972)

2. Cerasi, E.: Mechanisms of glucose stimulated insulin secretion in health and in diabetes: some re-evaluation and proposals. Diabetologia 11, 1-13 (1975)

3. Coleman, D. L., Hummel, K. P.: Studies with the mutation diabetes in the mouse. Diabetologia 3, 238-248 (1967)

4. Dulin, W.D., Wyse, B.M.: Diabetes in the KK mouse. Diabetologia 6, 317-323 (1970)

5. Faloona, G. R., Unger, R. H.: Glucagon, In: Methods of hormone radio-immunoassay. Jaffe, B. M., Behrman, H. R. (Eds.), pp. 317-330. New York: Academic Press 1972

6. Freychet, P., Roth, J., Neville, D. M., Jr.: Monoiodoinsulin: demonstration of its biological activity and binding to fat cells and liver membranes. Biochem. Biophys. Res. Commun. 43, 400-408 (1971)

7. Gerritsen, G. C., Blanks, M. C.: Preliminary studies on food and water consumption of prediabetic chinese hamsters. Diabetologia 6, 177-179 (1970)

8. Gonet, A. E., Stauffacher, W., Pictet, R., Mougin, J., Renold, A. E.: Obesity and diabetes mellitus with striking congenital hyperplasia of the islets of Langherans in spiny mice. Diabetologia 1, 162-171 (1965)

9. Gutzeit, A., Rabinovitch, A., Karakash, C., Stauffacher, W., Renold, A. E., Cerasi, E.: Evidence for decreased sensitivity to glucose of isolated islets Spiny mice. Diabetologia 10, 661-665 (1974)

10. Hackel, D. B., Milkat, E., Lebovitz, H. E., Schmidt-Nielsen, K., Horton, E. S., Kinney, T. D.: The sand rat as an experimental animal in studies of diabetes mellitus. Diabetologia $\mathbf{3}$, 130-134 (1967)

11. Hellerström, C., Andersson, A., Gunnarsson, R.: Regeneration of islet cells. Acta Endocrinol. [Suppl.] (Kbh.) 83, 145-160 (1976)

12. Huggett, A. S., Nixon, D. A.: Use of glucose-oxydase peroxidase and $\mathrm{O}$-dianiside in determination of blood and urinary glucose. Lancet 1957 II, 368-370

13. Jarrousse, C., Rançon, F., Rosselin, G.: Hormonogénèse périnatale de l'insuline et du glucagon chez le rat. C. R. Acad. Sci. [D] (Paris) 276, 585-588 (1973)

14. Lemonnier, D., Suquet, J. P., Aubert, R., Rosselin, G.: Long- 
term effect of mouse neonate food intake on adult body composition, insulin and glucose serum levels. Horm. Metab. Res. 5, 223-224 (1973)

15. Nottey, J. J., Rosselin, G.: Monoiodoglucagon: preparation, isolement, identification, contrôle radio-immunologique. C. R. Acad. Sci. [D] (Paris) 273, 2118-2121 (1971)

16. Ostman, J.: Adipose tissue metabolism and glucose tolerance in obese subjects during prolonged fasting. In: Proceedings of the $6^{\text {th }}$ Congress of the International Diabetes Federation 1967. Ostman, J., Milner, R. D. G. (Eds.), pp. 550-557. Amsterdam: Excerpta Medica Foundation 1969

17. Portha, B., Levacher, C., Picon, L., Rosselin, G.: Diabetogenic effect of streptozotocin in the rat during the perinatal period. Diabetes 23, 889-895 (1974)

18. Pupo, A. A., Ursich, M. J.J., Iamaguchi, E., Vasconcellos, F. G.: Acute and late-phase insulin secretion and glucose tolerance in mild alloxan diabetes in dogs. Diabetes 25, 161-166 (1976)

19. Rabinovitch, A., Gutzeit, A., Renold, A. E., Cerasi, E.: Insulin secretion in the Spiny mouse (Acomys Cahirinus). Dose and time kinetic studies with glucose in vivo and in vitro. Diabetes 24, 1094-1100 (1975)

20. Rosselin, G., Assan, R., Yalow, R. S., Berson, S. A.: Separation of antibody-bound and unbound peptide hormones labeled with iodine 131 by talcum powder and precipitated silica. Nature 212, 355-357 (1966)

21. Rosselin, G., Dolais, J.: Application de la méthode radioimmunologique au dosage de l'insuline humaine et au dosage de l'hormone folliculo-stimulante (H. FSH). Monographie ann. Sté Fse Biol. Clin. 1, 189-217 (1967)
22. Sodoyez-Goffaux, F., Sodoyez, J. C.: Transient diabetes mellitus in a neonate. J. Pediatr. 91, 395-399 (1977)

23. Stauffacher, W., Lambert, A. E., Vecchio, D., Renold, A. E.: Measurements of insulin activities in pancreas and serum of mice with spontaneous (obese and New Zealand obese) and induced (goldthioglucose) obesity and hyperglycemia, with considerations on the pathogenesis of the spontaneous syndrome. Diabetologia 3, 230-237 (1967)

24. Stauffacher, W., Orci, L., Amherdt, M., Burr, I. M., Balant, L., Froesch, E. R., Renold, A. E.: Metabolic state, pancreatic insulin content and cell morphology of normoglycemic spiny mice: indication for an impairment of insulin secretion. Diabetologia 6, 330-342 (1970)

25. Sun, A. M., Coddling, J. A., Haist, E. E.: A study of glucose tolerance and insulin response in partially depancreatized dogs. Diabetes 23, 424-432 (1974)

Received: November 30, 1978,

and in revised form: July 5, 1979

\section{Dr. Bernard Portha}

Laboratoire de Physiologie du Dévelopment Tour 23/33

Université Paris VII

2, Place Jussieu

F-75005 Paris

France 